\title{
ESTIMASI DEFORMASI INTERSEISMIC DI DAERAH PANTAI BENGKULU BAGIAN SELATAN DENGAN MENGGUNAKAN METODE SURVEY GPS GEODETIK
}

\author{
Ashar Muda Lubis*, Mia Wahyu, Rio Sahputra, Rida Samdara \\ Jurusan Fisika, Fakultas Matematika dan Ilmu Pengetahuan Alam, Universitas Bengkulu \\ *Penulis Korespondensi : asharml@unib.ac.id
}

\begin{abstract}
Abstrak. Telah dilakukan pengamatan deformasi pada kawasan pesisir pantai dalam siklus interseismic dengan menggunakan Global Positioning System (GPS) pada lima titik pemantauan di wilayah Bengkulu bagian selatan. Pengamatan GPS dilakukan dalam kurun waktu 2019-2020 kecuali untuk stasiun DEYU pada kurun waktu 2014-2016. Pengolatan data GPS dilakukan dengan menggunakan software GAMIT/GLOBK. Hasil pengolahan berupa posisi harian GPS time series dalam komponen utara dan timur yang kemudian dilakukan linear fit untuk mendapatkan vektor pergeseran. Kecepatan pergerakan pada stasiun GPS berada 22,23-27,67 mm/tahun dengan error pengukuran $<2,5 \mathrm{~mm} /$ tahun. Dari hasil penelitian ini menunjukkan adanya aktivitas deformasi interseismic di wilayah pesisir Bengkulu bagian selatan dengan arah vektor pergeseran hasil pengamatan menuju ke arah timur laut. Vektor pergerakan interseismic yang teramati masih perlu dikoreksi terhadap rotasi Blok Sunda, sehingga vektor pergerakan interseismic yang diperoleh hanya berasal dari pergerakan zona subduksi Sumatera dan sesar Sumatra yang berguna sebagai input pada pemodelan potensi kegempaan di Sumatra khususnya di daerah Bengkulu.
\end{abstract}

Kata Kunci: Bengkulu bagian selatan; GPS; vektor; deformasi; interseismik

\begin{abstract}
Deformation observations have been conducted in the coastal area during the interseismic cycle phases using the Global Positioning System (GPS) at 5 monitoring points in the southern part of Bengkulu. GPS observations were carried out in the period 2019-2020 except for DEYU stations in the period 20142016. GAMIT / GLOBK software was utilized process the GPS data. The obtained results are time series daily GPS positions in the north and east components. To obtain vector deformations a linear fit model was carried out. The velocity deformations at GPS stations are 22.23-27.67 mm/year with a measurement error of $<2.5 \mathrm{~mm} /$ year. The results indicate the existence of interseismic deformation activity in the southern coastal area of Bengkulu with the vector shifting of the observations towards the northeast. The observed interseismic movements still need to be corrected for the rotation of the Sunda Block, so that the interseismic deformation only comes from Sumatra subduction zone and Sumatra fault which is useful as input for modeling potential seismicity in Sumatra, especially in the Bengkulu area.
\end{abstract}

Keywords: Southern Bengkulu; GPS; vector; deformation; interseismic

\section{PENDAHULUAN}

Aktivitas tektonik di Sumatra ditandai dengan tumbukan lempeng Indo-Australia dengan lempeng Eurasia dengan kecepatan 50-70 mm/tahun (Bock dkk., 2003). Perbedaan densitas pada lempeng IndoAustralia dengan lempeng Eurasia, maka IndoAustralia menujam di bawah lempeng Eurasia. Batas antara lempeng yang menunjam ini disebut sebagai bidang kotak dari zona penunjaman atau zona subduksi Sumatra (Bock dkk., 2003).

Sebab terdapatnya dorongan menerus dari lempeng Indo-Australia menimbulkan terbentuknya penumpukan tenaga di dasar lempeng Eurasia pada pertemuan dengan lempeng Indo-Australia, sehingga lama-lama terjadi gempa bumi. Contoh gempa besar yang terjadi di daerah Bengkulu terjadi pada 12 September 2007 (Mw 8,4) dengan episenter di daerah perairan Bengkulu (Lubis dkk., 2013) dan gempa bumi 4 Juni 2000 (Mw 7,9) yang juga di perairan Bengkulu (Ammani dkk., 2010).

Pada saat terjadi gempa bumi, maka terjadi deformasi elastik. Peristiwa ini disebut sebagai fase co-seismic dalam siklus gempa bumi. Dalam satu siklus gempa bumi ada beberapa tahapan proses deformasi, yaitu tahapan interseismic, co-seismic, dan post-seismic (Sarsito dkk., 2005).

Tahapan interseismic merupakan tahap awal dari suatu siklus gempa bumi dan sangat penting untuk diteliti untuk pemahaman potensi kegempaan dan untuk melihat fenomena perubahan muka tanah 
(Schumm dkk., 2002). Pada siklus interseismic aktivitas permukaan tanah bisa mengalami kenaikan dan penurunan yang dapat menyebabkan perubahan tinggi daratan dalam waktu yang sangat panjang. Oleh karena itu penelitian ini bertujuan untuk memetakan deformasi interseismic di daerah Bengkulu khususnya Bengkulu Selatan. Purwanto dkk., (2016) telah melakukan penelitian segmentasi daerah interseismic dan post-seismic di Provinsi Bengkulu dengan menggunakan data Global Positioning System (GPS) tahun 2007-2016. Akan tetapi untuk daerah selatan data GPS masih terbatas, sehingga untuk pemetaan deformasi interseismic masih sangat minim terutama untuk kepentingan menghitung strain accumulation akibat pergerakan plate tektonik.

Pengukuran deformasi interseismic bisa dicoba dengan pendekatan Geodesi ialah memanfaatkan teknologi Interferometry Synthetic Aperture Radar (InSAR) serta teknologi Global Positioning System (GPS). Teknologi InSAR adalah teknologi Geodesi yang dikembangkan untuk pengamatan deformasi dengan akurasi centimeter (Abidin, 2001). Tetapi teknologi GPS mempunyai orde ketelitian yang lebih besar dibanding dengan InSAR. Teknologi GPS bisa memberikan nilai vektor deformasi kerak bumi dalam 3 ukuran, maksudnya GPS bisa membagikan data deformasi dalam arah horizontal serta vertikal dengan tingkatan presisi hingga orde $\mathrm{mm}$ (Abidin dkk., 2009). Di samping itu GPS dapat digunakan tanpa bergantung waktu dan cuaca, sehingga dalam pengamatan deformasi interseismic di Bengkulu bagian selatan digunakan teknologi GPS.

\section{METODOLOGI}

Penelitian dimulai dengan survey pemasangan monumen GPS di daerah Bengkulu Selatan. Lokasi tempat monumen yang akan dibangun dipilih berdasarkan kemudahan melihat satelit GPS dan kestabilan tanah lokasi pendirian monumen. Hal yang penting juga diperhatikan yakni izin mendirikan monumen dan keamanan monumen setelah dibangun dan diatur sebagai stasiun pengamatan GPS. Kemudian dilakukan instalasi jaringan GPS. Instalasi jaringan GPS dilakukan dengan pemasangan adaptor ke antena sebagai tempat dudukan antena ke monumen. Setelah selesai memasang antena, kemudian dilakukan pemasangan kabel ke antena untuk menghubungkan antena dengan receiver dan memasang solar panel sebagai penghasil sumber arus listrik. Solar panel dihubungkan dengan cas control, lalu dari cas control dihubungkan dengan receiver agar receiver mendapat arus listrik, sehingga menghasilkan instalasi jaringan GPS yang baik seperti pada Gambar 1.

Monumen dan stasiun yang telah diinstal sebanyak 5 titik pengamatan yang terletak di daerah sepanjang pesisir pantai Bengkulu bagian selatan yaitu DEYU, SLMA, PDPJ, IMAN dan MAJE (Tabel 1). Monumen terbuat dari coran semen dengan tinggi 2 $\mathrm{m}$ dari permukaan tanah dengan ketebalan $40 \mathrm{~cm} x$ $40 \mathrm{~cm}$. Contoh monumen dan peralatan pada stasiun pemantauan dengan menggunakan GPS diperlihatkan pada Gambar 1. Pengambilan data GPS dilakukan pada selang waktu 2019-2020, kecuali untuk stasiun pengamatan DEYU karena pada stasiun in telah dilakukan pengambilan waktu yang terpisah sebelumnya. Pengambilan data menggunakan GPS geodetik Hi-Target Target CORS Vnet8 dengan resolusi orde $\mathrm{mm}$.

Sebelum dilakukan pengolahan data pengamatan GPS, raw data GPS terlebih dahulu dikonversi kedalam bentuk format Receiver Independent Exchange (RINEX). Kemudian dicek kualitasnya dengan menggunakan software TEQC. Secara umum kualitas data sangat baik ditandai dengan adanya pengamatan sinyal L1 dan L2 dengan interval pengamatan tiap 30 detik. Selanjutnya dilakukan pengumpulan data sekunder seperti data navigasi dan data satellite precise phemeris (sp3). Data lainnya yang diperlukan yakni data titik ikat IGS stasiun, data atmosfer, data gelombang pasang surut dan data, pemodelan cuaca yang dapat didownload melalui ftp://everest.mit.edu/pub/GRIDS/ dan diunduh dari Scripps Orbit and Permanent Array Center (SOPAC). Data-data ini digunakan untuk menghitung deformasi yang berasal dari tekanan akibat pasang surut dan akibat tekanan atmosfer. Pasang surut dapat mempengaruhi estimasi deformasi yang diamati oleh GPS (Gökhan dan Jin, 
2016; Jiang-cun, 2007; Li dkk., 2014; Wang, 2005), demikian juga halnya dengan tekanan atmosfer (Huang dkk., 2005; Luo dan Sun, 2000; Yue dkk., 2020).

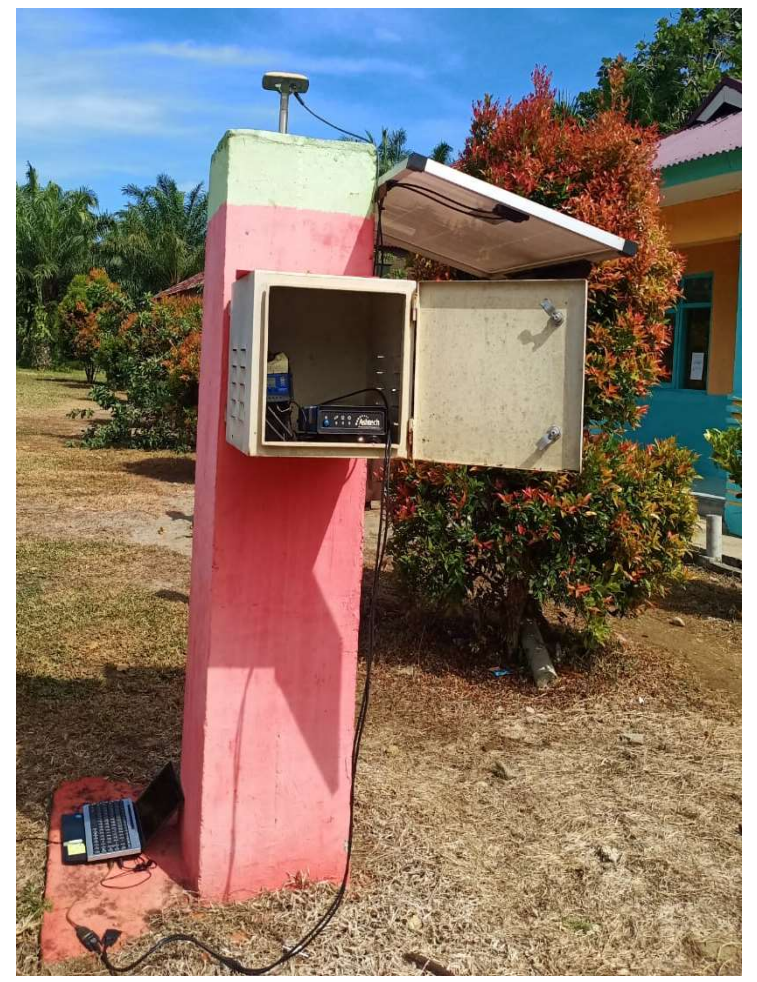

Gambar 1. Stasiun GPS PDPJ pemantau deformasi yang telah dibangun di daerah Manna, Bengkulu.

Selatan

Pengolahan data GPS dilakukan dengan menggunakan software GNSS at MIT dan Global Kalman filter yang disebut dengan GAMIT/GLOBK (King R dan Bock, 2000). Hasil dari pengolahan data GPS dengan software GAMIT didapatkan berupa solusi posisi dalam bentuk lossy constraint dan nilai kovariannya ( $h$-file). Kumpulan $h$-file yang diperoleh termasuk dari titik ikat seperti pada stasiun pengamatan GPS BAKO, COCO, XMIS, DARW, NTUS dan PIMO digunakan untuk pengolahan dengan perangkat lunak GLOBK untuk mendapatkan posisi harian dan estimasi kecepatan pergerakan stasiun pengamatan dalam komponen horizontal (arah utara $(V n)$ dan timur $(V e))$. Pengamatan komponen vertikal $(\mathrm{Vu})$ tidak diamati pada penelitian ini mengingat komponen ini memiliki banyak dan diperlukan waktu pengamatan yang cukup lama

Hasil pengolahan data survei GPS yang berupa posisi harian tiap stasiun pengamatan digunakan untuk menentukan kecepatan vektor pergeseran. Kecepatan vektor pergeseran pada fase interseismic pada masing-masing stasiun pengamatan yang dapat ditentukan dengan metode least squared untuk komponen horizontal (arah utara $(V n)$ dan timur $(V e))$ dengan fungsi linier dan komponen variasi musiman yang berhubungan dengan ice-mass loading (Su dkk., 2020). Mengingat di Indonesia merupakan daerah tropis khususnya Sumatra, maka estimasi vektor pergeseran dapat disederhanakan (Tong dkk., 2018). Model linear seperti ini sudah lazaim digunakan dalam mengestimasi pergerakan interseismic (Chaussard dkk., 2015) yang dapat dirumuskan sebagai berikut:

$\mathrm{y}=\mathrm{ax}+\mathrm{b}$

Nilai konstanta a dan $b$ dapat ditentukan dengan menggunakan rumus (Walpole dan Myers, 1995):

$$
\begin{aligned}
& a=\frac{n(\Sigma X i Y i)-(\Sigma X i)(\Sigma Y i)}{n \Sigma X i^{2}-(\Sigma X i)^{2}} \\
& b=\frac{(\Sigma Y i)\left(\Sigma X i^{2}\right)-(\Sigma X i)(\Sigma X i Y i)}{n \Sigma X i^{2}-(\Sigma X i)^{2}}
\end{aligned}
$$

Tabel 1. Kecepatan pergerakan stasiun pada titik pengamatan GPS dalam mm/tahun dengan error $(\boldsymbol{\sigma})$ dan azimuth arah pergerakan stasiun GPS dari arah utara $\left({ }^{\circ}\right)$

\begin{tabular}{lllccccccc}
\hline No & Lokasi & Stasiun & Bujur & Lintang & Vn & Ve & $\sigma V n$ & $\sigma V e$ & Azimut \\
\hline 1 & Seluma & DEYU & $102^{\circ} 25^{\prime} 31^{\prime \prime}$ & $-3^{\circ} 58^{\prime} 56^{\prime \prime}$ & 7,54 & 26,63 & 1,10 & 0,75 & 74.23 \\
2 & Seluma & SLMA & $102^{\circ} 35^{\prime} 13^{\prime \prime}$ & $-4^{\circ} 04^{\prime} 57^{\prime \prime}$ & 7,15 & 21,08 & 1,51 & 1,84 & 71.30 \\
3 & Manna & PDPJ & $102^{\circ} 52^{\prime} 16^{\prime \prime}$ & $-4^{\circ} 24^{\prime} 54^{\prime \prime}$ & 5,34 & 23,61 & 1,79 & 2,08 & 77.29 \\
4 & Padang guci & IMAN & $103^{\circ} 12^{\prime} 01^{\prime \prime}$ & $-4^{\circ} 37^{\prime} 25^{\prime \prime}$ & 7,23 & 21,03 & 0,67 & 0,75 & 71.06 \\
5 & Bintuhan & MAJE & $103^{\circ} 26^{\prime} 54^{\prime \prime}$ & $-4^{\circ} 51^{\prime} 30^{\prime \prime}$ & 5,42 & 21,58 & 0,75 & 0,86 & 77.09 \\
\hline
\end{tabular}


dimana $\mathrm{x}$ adalah waktu pengamatan ke-i, dimana $\mathrm{i}$ merupakan posisi harian (tahun+sesi/365), kemudian y merupakan data posisi pada waktu $\mathrm{t}$ dalam arah utara dan timur. a merupakan kecepatan pergerakan stasiun GPS pada arah utara $(V n)$ dan timur ( $V e)$ ), sedangkan b merupakan konstanta perpotongan dengan sumbu posisi stasiun pengamatan.

\section{HASIL DAN PEMBAHASAN}

Hasil pengolahan data GPS dan fitting line untuk posisi harian GPS pada 5 stasiun diperlihatkan pada Gambar 2 sampai Gambar 6. Pada Gambar 2 dapat dilihat posisi hari GPS secara time series untuk stasiun pengamatan DEYU. Pada Gambar 2 terlihat bahwa posisi tahunan GPS untuk komponen utara bergerak sebesar 7,54 mm/tahun dan untuk komponen timur bergerak sebesar 26,63 mm/tahun. Error pengkuran untuk komponen utara dan timur relatif lebih kecil yakni $<2 \mathrm{~mm} /$ tahun.

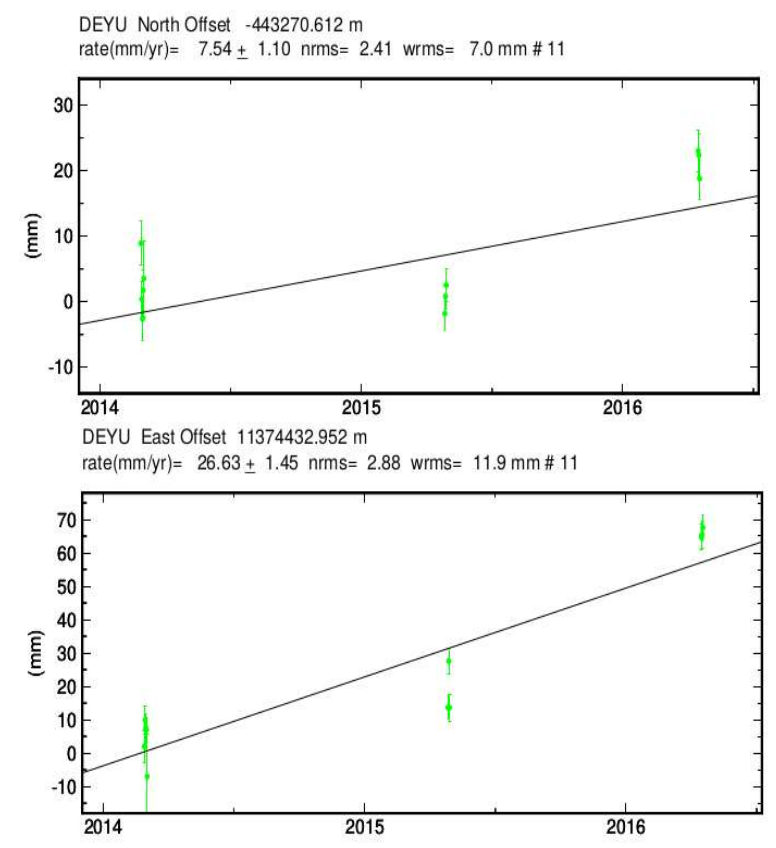

Gambar 4. Posisi tahunan GPS Stasiun Pengamatan DEYU untuk masing-masing komponen utara dan timur

Pada Gambar 3 diperlihatkan posisi harian secara time series untuk stasiun pengamatan GPS SLMA. Pada gambar ini menunjukkan bahwa pergerakan posisi tahunan GPS untuk komponen utara bergerak sejauh 7,15 $\mathrm{mm} /$ tahun dan komponen timur sejauh 21,08 mm/tahun. Error pengukuran pada stasiun GPS ini lebih besar dibandingkan dengan stasiun DEYU, akan tetap masih error untuk komponen utara dan timur masih dibawah 2,5 mm/tahun.

SLMA North Offset $-454453.136 \mathrm{~m}$

rate $(\mathrm{mm} / \mathrm{yr})=7.15 \pm 1.51 \mathrm{nrms}=0.77 \mathrm{wrms}=2.5 \mathrm{~mm} \# 29$
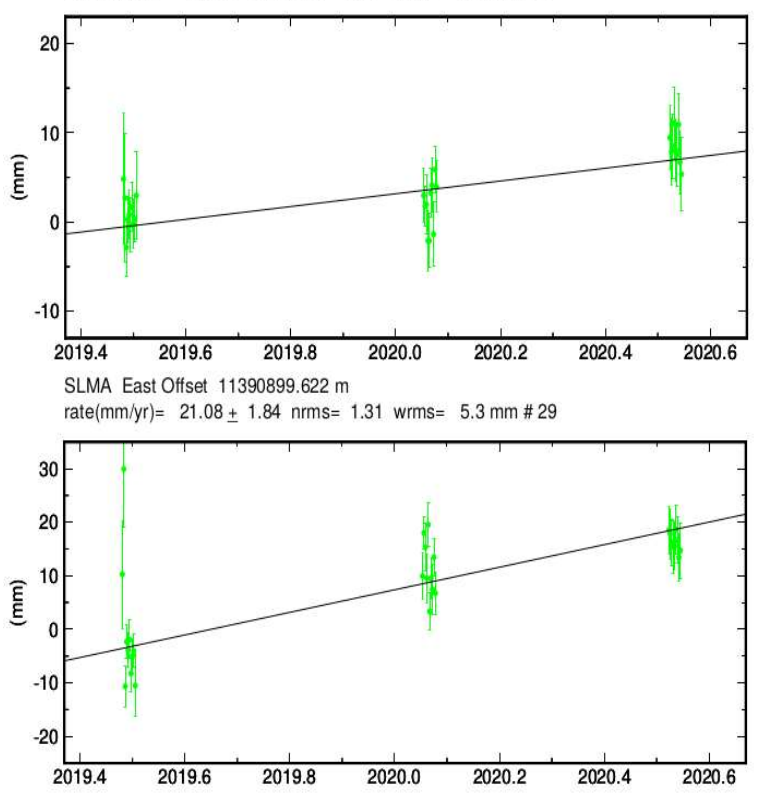

Gambar 2. Posisi tahunan GPS Stasiun Pengamatan SLMA untuk masing-masing komponen utara dan timur

PDPJ North Offset $-491420.110 \mathrm{~m}$

rate $(\mathrm{mm} / \mathrm{yr})=5.34 \pm 1.79 \mathrm{nrms}=0.64 \mathrm{wrms}=1.8 \mathrm{~mm} \# 102$

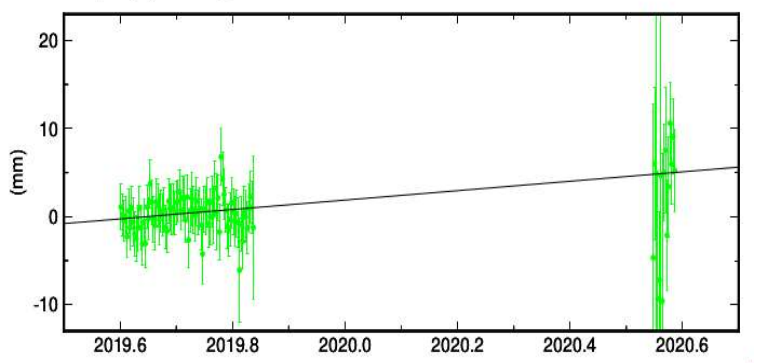

PDPJ East Offset $11417573.063 \mathrm{~m}$

$\operatorname{rate}(\mathrm{mm} / \mathrm{yr})=23.61 \pm 2.08 \mathrm{nrms}=1.15 \mathrm{wrms}=3.6 \mathrm{~mm} \# 100$

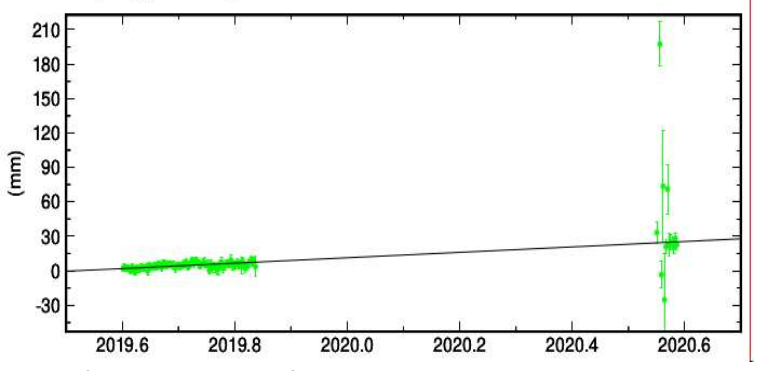

Gambar 3. Posisi tahunan GPS Stasiun Pengamatan

PDPJ untuk masing-masing komponen utara dan timur

Kemudian posisi harian GPS untuk stasiun pengamatan PDPJ secara time series dari tahun 2019-2020 diperlihatkan pada Gambar 4. 
Dapat dilihat bahwa pergerakan posisi tahunan GPS stasiun PDPJ untuk komponen utara bergerak sebesar 5,34 mm/tahun dan komponen timur sebesar 23,61 mm/tahun. Kesalahan dari model linear fit untuk komponen utara dan timur sangat kecil yakni $<1 \mathrm{~mm} /$ tahun.

Pada Gambar 5 diperlihatkan posisi harian GPS untuk stasiun pengamatan IMAN. Dapat dilihat bawah pergerakan posisi tahunan pada stasiun pengamatan IMAN untuk komponen utara bergerak sebesar 7,23 mm/tahun dan untuk komponen timur sebesar 21,03 mm/tahun. Sementara itu, kesalahan dari model linear fit untuk komponen utara dan timur mirip dengan stasiun GPS PDPJ yakni $<1$ $\mathrm{mm} /$ tahun.

IMAN North Offset $-514638.188 \mathrm{~m}$

rate $(\mathrm{mm} / \mathrm{yr})=7.23 \pm 0.67 \mathrm{nrms}=0.72 \mathrm{wrms}=2.4 \mathrm{~mm} \# 206$
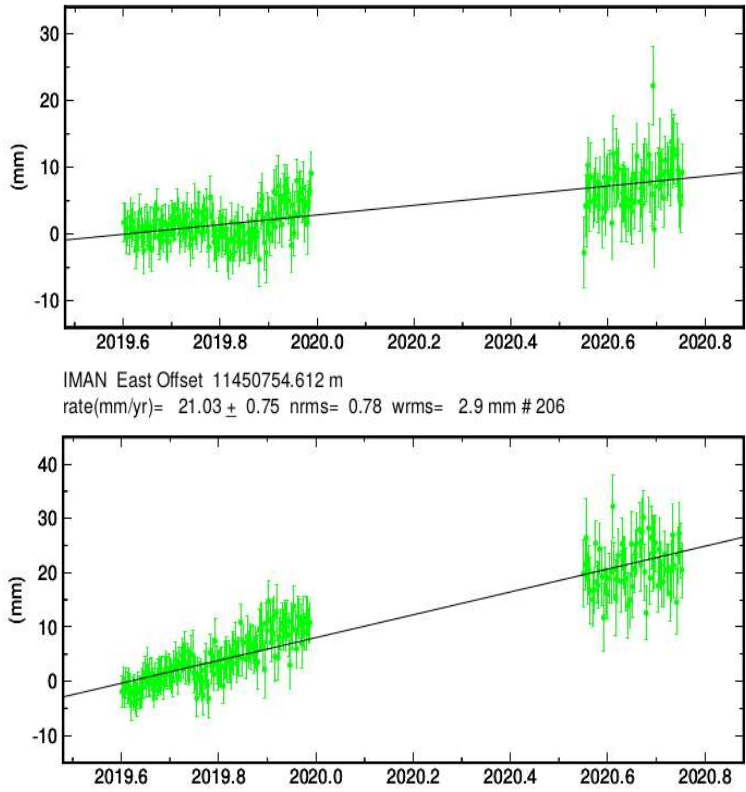

Gambar 5. Posisi tahunan GPS Stasiun Pengamatan IMAN untuk masing-masing komponen utara dan timur

Kemudian untuk posisi harian GPS secara time series pada stasiun MAJE dapat dilihat pada Gambar 6. Dapat dilihat pergerakan tahunan stasiun GPS untuk komponen utara sebesar 5,42 mm/tahun, sedangkan pergerakan untuk komponen timur sebesar 23,58 mm/tahun. Kesalahan dari model linear fit untuk komponen utara dan timur sangat kecil yakni $<1 \mathrm{~mm} /$ tahun, mirip dengan error pada stasiun pengamatan GPS PDPJ dan GPS IMAN.
Dari hasil pengamatan GPS secara time series dan estimasi model linear fit pada penelitian ini menunjukkan bahwa kecepatan pergerakan terbesar terlihat pada stasiun pengamatan DEYU dengan kecepatan pergerakan sebesar 27,67 mm/tahun (Tabel 1). Sementara itu kecepatan pergerakan terkecil terdapat pada titik pengamatan GPS IMAN dengan kecepatan pergerakan sebesar 22,23 $\mathrm{mm} /$ tahun.

Dari hasil pengamatan linear fit untuk komponen utara dan timur pada Gambar 2 sampai Gambar 6, maka vektor kecepatan pergerakan pada stasiun-stasiun pengamatan GPS dapat dihitung. Gambar 7 menunjukkan vektor pergerakan lempeng tektonik data hasil pengamatan GPS pada fase interseismic relatif terhadap International Terrestrial Reference Frame (ITRF) 2008. Fase interseismic merupakan tahap awal dari suatu siklus gempa bumi, pada fase ini energi dari dalam bumi menggerakkan lempeng-lempeng tektonik yang lama-kelamaan akan terjadi akumulasi energi di bagian lempeng tempat terjadi gempa bumi (Sarsito dkk., 2005).

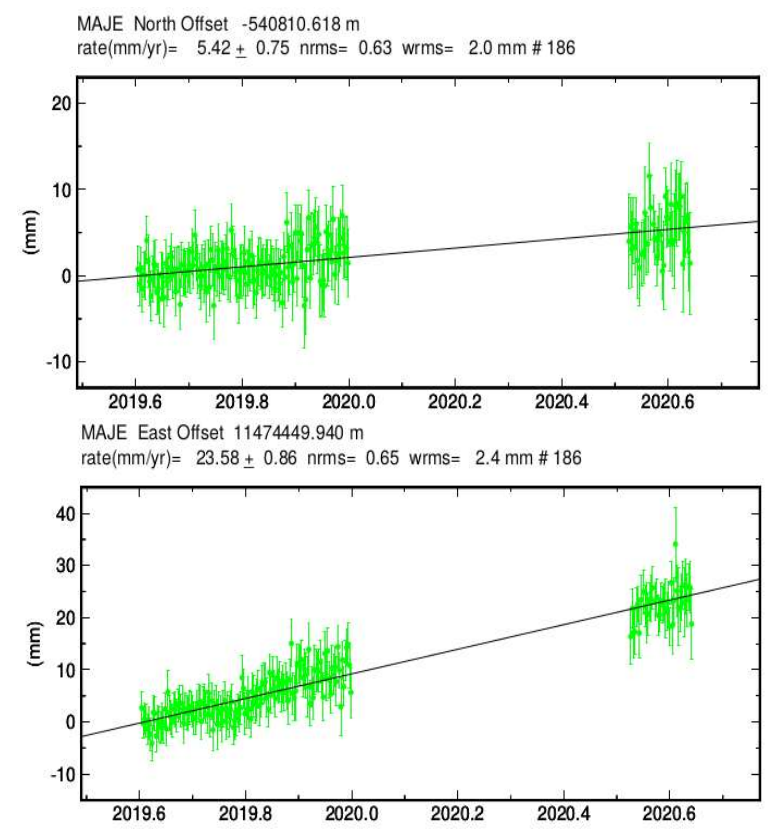

Gambar 6. Posisi tahunan GPS Stasiun Pengamatan MAJE untuk masing-masing komponen utara dan timur

Besar nilai vektor pergeseran pada 5 titik pengamatan yaitu stasiun DEYU, SLMA, PDPJ, IMAN, dan MAJE secara berurutan yaitu sebesar 27,67 $\mathrm{mm} /$ tahun, $22,25 \mathrm{~mm} /$ tahun, $24,20 \mathrm{~mm} /$ tahun, 
$22,23 \mathrm{~mm} / \operatorname{tahun}$, dan $24,19 \mathrm{~mm} /$ tahun. Hasil dari data pengamatan GPSS menunjukkan bahwa arah vektor pergeseran pada titik pengamatan menuju ke arah timur laut sesuai dengan penelitian yang telah dilakukan oleh Prawirodirdjo dkk., (1997).

Adanya fase interseismic yang terjadi di wilayah Bengkulu bagian selatan menunjukkan daerah ini mengalami salah satu fase siklus gempa bumi setelah kejadian gempa bumi Bengkulu 4 Juni 2000 (Mw 7.9) (Ammani dkk., 2010). Arah pergeseran titik-titik GPS yang bergerak ke arah daratan mirip dengan yang diperoleh Purwanto dkk., (2016) dimana vektor pergeserannya menunjukkan kecenderungan pergerakan sesuai dengan arah pergerakan lempeng tektonik Indo-Australia yang menunjam lempeng Eurasia. Namun nilai pergerakan interseismic dalam Purwanto dkk., (2016) relatif lebih kecil. Hal ini dapat dimengerti karena pada selang 2007-2016 masih dipengaruhi oleh post-seismic gempa bumi pada 12 September 2007 (Mw 8.4) dengan episenter di daerah perairan Bengkulu (Lubis et al., 2013). Namun demikian pemantauan pergerakan tektonik pada stasiun GPS diperlukan secara terus menerus dalam rangka meng-cupture siklus kegempaan di Sumatra bagian selatan khususnya di daerah Bengkulu bagian selatan.
Vektor pergerakan interseismic yang teramati pada stasiun titik pengamatan GPS masih dipengaruhi oleh gerak relatif plate tektonik IndoAustralia dan Eurasia frame secara global. Untuk mendapatkan kecepatan pergerakan stasiun titik pengamatan GPS yang hanya dipengaruhi oleh pergerakan pada zona subduksi Sumatera dan pada sesar Sumatra saja maka kedepan nilai kecepatan pergerakan yang didapatkan dari GPS perlu dikoreksi rotasi terhadap Blok Sunda. Selain itu diperlukan juga pemisahan kompenen interseismic yang berasal dari pada zona subduksi Sumatera dan pada sesar Sumatra, hal ini berguna dalam memodelkan potensi kegempaan pada segmen zona subduksi Sumatra bagian selatan dan kegempaan pada sesar Sumatra khususnya pada segmen Manna.

\section{PENUTUP}

\section{Simpulan dan Saran}

Berdasarkan penelitian yang telah dilakukan dengan menggunakan metode GPS menunjukkan bahwa daerah pengamatan wilayah pesisir pantai Bengkulu bagian selatan mengalami fase deformasi interseismic. Pada lima titik pengamatan yaitu titik DEYU, SLMA, PDPJ, IMAN dan MAJE menunjukkan deformasi interseismic bergeser ke arah timur laut,

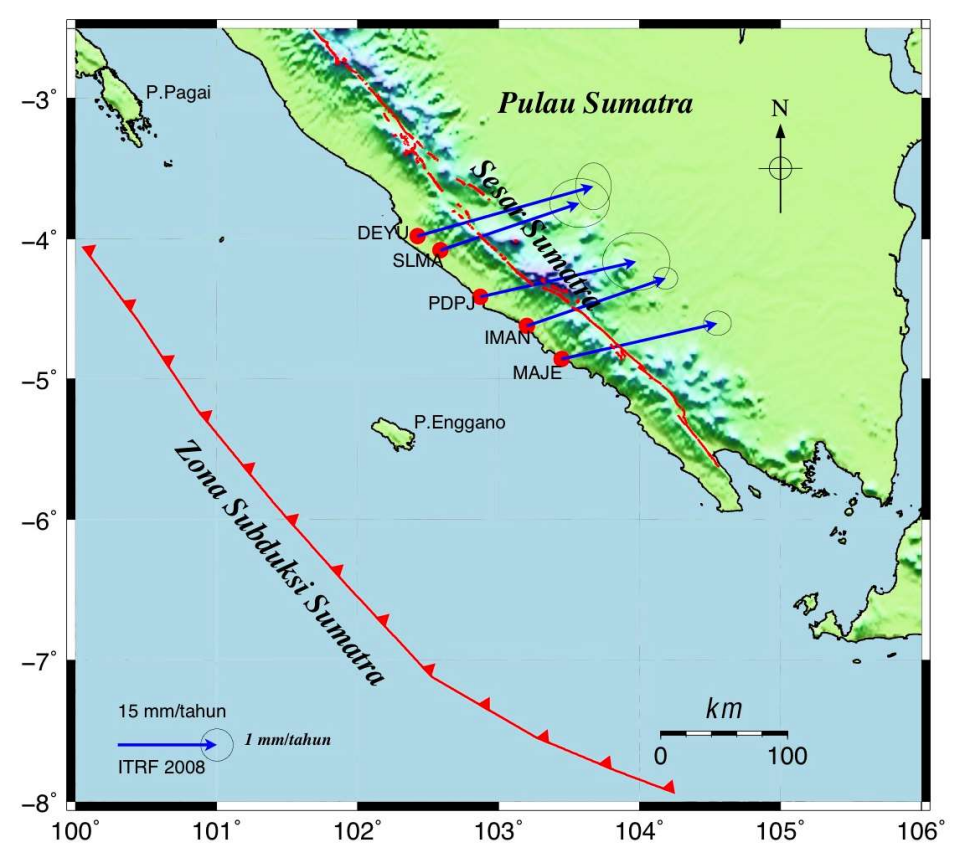

Gambar 7. Vektor pergerakan dari hasil pengukuran GPS (vektor biru). Error vektor (lingkaran terbuka hitam). Titiktitik merah merupakan lokasi titik pengamatan GPS 
lebih tepatnya $71^{\circ}-77^{\circ}$ dari arah utara. Besar nilai kecepatan vektor pergerakan pada lima titik pengamatan berdasarkan data pengamatan GPS di masing-masing lokasi penelitian ialah: pada stasiun DEYU sebesar 27,67 mm/tahun, Stasiun SLMA sebesar 22,25 mm/tahun, pada stasiun PDPJ sebesar 24,20 mm/tahun, Stasiun IMAN sebesar 22,23 $\mathrm{mm} /$ tahun dan stasiun MAJE sebesar 24,19 $\mathrm{mm} /$ tahun. Kedepan pemantauan pergerakan tektonik pada stasiun GPS diperlukan secara terus menerus dalam rangka penyedikian interseismic dalam siklus kegempaan di daerah Bengkulu bagain selatan yang berguna untuk pemetaan potensi gempaan di wilayah ini. Infromasi ini sangat penting untuk perencanaan dan mitigasi bahaya gempa bumi pada suatu kawasan.

\section{Ucapan Terima Kasih}

Terima kasih kepada program Demand Driven Research Grant (DDRG) tahun 2019 atas pendanaan penelitian melalui kegiatan Coral Reef Rehabilitation and Management Program-Coral Triangle Initiative (COREMAP-CTI), LIPI. Peralatan GPS difasilitasi program Hibah PEER USAID tahun 2015-2018. Ucapan terima kasih juga kepada Jurusan Fisika FMIPA UNIB yang telah mendanai pengambilan data GPS di lapangan.

\section{DAFTAR PUSTAKA}

Abidin, H.Z. (2001), Geodesi Satelit, PT Pradnya Paramita, Jakarta.

Abidin, H.Z., Andreas, H., Meilano, I., Gamal, M., Gumilar, I. dan Abdullah, C. (2009), "Deformasi Koseismik dan Pascaseismik Gempa Yogyakarta 2006 dari Hasil Survei GPS", Indonesian Journal on Geoscience, Vol.4, No.4, hal. 275-284. http://doi.org/10.17014/ijog.v4i4.87.

Ammani, A., Catherine, J., Gahalaut, V.K., Narsaiah, M., Bansal, A. dan Mahesh, P. (2010), "The 2007 Bengkulu earthquake, its rupture model and implications for seismic hazard", Journal of Earth System Science, Vol.119, No.4, hal. 553-560. http://doi.org/10.1007/s12040-010-0037-2.

Bock, Y., Prawirodirdjo, L., Genrich, J., Stevens, C., Mccaffrey, R., Subarya, C., Puntodewo, S. dan Calais, E. (2003), "Crustal motion in Indonesia from Global Positioning System measurements", Journal of
Geophysical Research, Vol.108. http://doi.org/10.1029/2001JB000324.

Chaussard, E., Burgmann, R., Fattahi, H., Johnson, C., Nadeau, R., Taira, T. dan Johanson, I. (2015), "Interseismic coupling and refined earthquake potential on the Hayward-Calaveras fault zone", Journal of Geophysical Research: Solid Earth, Vol.120, hal. 8570-8590. http://doi.org/10.1002/2015JB012230.

Gökhan, G. dan Jin, S. (2016), "Evaluation of ocean tide loading effects on GPS-estimated precipitable water vapour in Turkey", Geodesy and Geodynamics, Vol.7, No.1, hal. 32-38. http://doi.org/10.1016/j.geog.2015.12.008.

Huang, Y., Guo, J.-Y., Huang, C. dan Hu, X. (2005), "Theoretical Computation of Atmospheric Gravity Green's Functions", Chinese Journal of Geophysics, Vol.48, No.6, hal. 1295-1301. http://doi.org/10.1002/cjg2.785.

Jiang-cun, S.H.Z. (2007), Loading Effect on High Precision GPS http://doi.org/10.11867/J.ISSN.10018166.2007.10.1036.

King R dan Bock, Y. (2000), Documentation for the GAMIT GPS analysis software, Massachusetts, Department of Earth, Atmospheric, and Planetary Science Massachusetts Institute of Technology Department of Earth, Atmospheric, and Planetary Science, Masschusetts Institute of Technology,.

Li, Z., Jiang, W., Ding, W., Deng, L. dan Peng, L. (2014), "Estimates of Minor Ocean Tide Loading Displacement and Its Impact on Continuous GPS Coordinate Time Series", Sensors, Vol.14, No.3, hal. 5552-2272. http://doi.org/10.3390/s140305552.

Lubis, A., Hashima, A. dan Sato, T. (2013), "Analysis of afterslip distribution following the 2007 September 12 southern Sumatra earthquake using poroelastic and viscoelastic media", Geophysical Journal International, Vol.192, hal. 18-37. http://doi.org/10.1093/gji/ggs020.

Luo, S.C. dan Sun, H.P. (2000), "The influences of the air pressure change on gravity at Wuhan station", Acta Geodaetica et Cartographica Sinica, Vol.29, No.S1, hal. 75-79.

Prawirodirdjo, L., Bock, Y., Mccaffrey, R., Genrich, J., Calais, E., Puntodewo, S., Subarya, C., Rais, J., Zwick, P., dan Fauzi (1997), "Geodetic Observations of Interseismic Strain Segmentation at the Sumatra Subduction Zone", Geophysical Research Letters, Vol.24, No.21, hal. 2601-2604. http://doi.org/10.1029/97GL52691. 
Purwanto, E., Iwan, S. dan Ashar, M.L. (2016), Identifikasi Arah Deformasi Postseismik/Interseismik Di Daerah Bengkulu Dengan Menggunakan Pengamatan GPS Periode 2007-2016, Skripsi, Universitas Bengkulu, Bengkulu. Diambil dari http://repository.unib.ac.id/16003/.

Sarsito, D.A., Andreas, Meilano, I., Darmawan, D. dan Gamal, M. (2005), "Implikasi Co-Seismic dan PostSeismic Horisontal Displacement Gempa Aceh 2004 terhadap Status Geometrik Data Spasial Wilayah Aceh dan Sekitarnya", Kelompok Keahlian Geodesi, Departemen Teknik Geodesi, Institut Teknologi Bandung, Bandung,.

Schumm, S.A., Dumont, J.F. dan Holbrook, J.M. (2002), Active Tectonics and Alluvial Rivers, Cambridge University Press, Cambridge.

Su, L., Shi 石富强, F., Gan, W., Xiaoning, su dan Yan, J. (2020), "Probing time-dependent afterslip and viscoelastic relaxation following the $2015 \mathrm{Mw} 7.8$ Gorkha earthquake based on the 3-D Finite Element Model", Earth Planets Space, Vol.72, No.168. http://doi.org/10.1186/s40623-020-01296-x.

Tong, X., Sandwell, D. dan Schmidt, D. (2018), "Surface Creep Rate and Moment Accumulation Rate Along the Aceh Segment of the Sumatran Fault From L-band ALOS-1/PALSAR-1 Observations", Geophysical Research Letters, Vol.45, hal. 3404-3412. http://doi.org/10.1002/2017GL076723.

Walpole, R.E. dan Myers, R.H. (1995), Ilmu Peluang dan Statistika untuk Insinyur dan IImuwan, 4 Ed., ITB Press, Bandung.

Wang, M. (2005), "Effects of Non-Tectonic Crustal Deformation on Continuous GPS Position Time Series and Correction to Them", Chinese Journal of Geophysics, Vol.48, No.5, hal. 1045-1052.

Yue, C., Dang, Y., Xu, C., Gu, S. dan Dai, H. (2020), "Effects and Correction of Atmospheric Pressure Loading Deformation on GNSS Reference Stations in Mainland China", Mathematical Problems in Engineering, hal. 110. http://doi.org/10.1155/2020/4013150. 